\title{
ANALISIS PENGAKUAN PENDAPATAN DAN BEBAN SERTA PENGARUH TERHADAP LAPORAN KEUANGAN PADA PERUSAHAAN MIDEAST TOUR AND TRAVEL PAMEKASAN
}

\author{
Runik Puji Rahayu \\ Nurul Alfian \\ Universitas Madura
}

\begin{abstract}
ABSTRAK
Perusahaan Mideast Tour and Travel bergerak di bidang jasa perjalanan haji dan umroh. Di setiap tahunnya perusahaan selalu memiliki promo-promo yang menarik untuk para calon jamaah. Dengan adanya promo-promo tersebut peneliti sangat tertarik dalam meneliti laporan keuangan perusahaan khususnya di bagian pengakuan pendapatan dan beban. Peneliti ingin mengetahui pengakuan pendapatan dan beban yang diterapkan pada perusahaan. Yang nantinya akan melihat dampak yang timbul dalam pencatatan laporan keuangan perusahaan.

Pengakuan pendapatan dan beban perusahaan menggunakan metode cash basic. Dimana perusahaan mencatat laporan keuangannya ketika terdapat kas masuk ataupun kas keluar. Adapun dampak yang akan diperoleh perusahaan pada pencatatan ini perusahaan tidak dapat mengetahui biaya dan pendapatan perusahaan dalam satu periode. terkadang perusahaan mengalami laba yang meningkat, terkadang pula mengalami penurunan laba yang derastis. Keadaan tersebut yang membuat laporan keuangan perusahaan Mideast Tour and Travel tidak dapat dibuktikan kebenarannya dikarnakan adanya pengakuan pendapatan dan beban yang kurang tepat. Akhirnya dampak dari pencatatan yang seperti inilah perusahaan tidak dapat melaporkan laporan keuangannya dengan akurat sesuai PSAK yang berlaku. Pada penelitian kali ini penulis memberi perbandingan terhadap laporan keuangan perusahaan dengan laporan keuangan yang menggunakan standart yang berlaku di Indonesia. Dan hasilnya terdapat selisih yang tidak sama satu sama lain dengan tahun-tahun sebelumnya. oleh karnanya peneliti dapat menyarankan perusahaan dapat mengganti laporan keuangan cash basic tersebut dengan laporan keuangan yang mengacu pada PSAK yang berlaku di Indonesia yaitu laporan keuangan dengan metode accrual basic. Laporan keuangan cash basic memang lebih gampang digunakan,namun pengakuan yang dimiliki nantinya akan tidak benar dengan kenyataan didalam perusahaan.
\end{abstract}

Kata kunci : Mideast Tour and Travel, Cash Basic, Accrual Basic 


\section{Pendahuluan}

Setiap perusahaan tidak terkecuali perusahaan jasa, selalu ada pencatatan pada saat terjadi transaksi keuangan. Entah itu pendapatan ataupun beban-beban yang perusahaan keluarkan.

Pendapatan merupakan jumlah uang yang diperoleh oleh perusahaan dari hasil aktifitas perusahaan. Disamping pendapatan dalam aktifitas usaha, terdapat pula pendapatan yang didapat dari non usaha yaitu pendapatan yang berasal dari kegiatan diluar usaha pokok, seperti misalnya pendapatan deviden, pendapatan bunga, dan atau pendapatan sewa.

Beban merupakan suatu biaya yang dikeluarkan perusahaan untuk mendapatkan sesuatu yang diinginkan. Beban juga dapat diartikan dengan pendapatan yang didapat perusahaan tetapi seseorang yang membayar belum merasakan jasa yang perusahaan berikan.

Sedangkan laporan keuangan itu sendiri merupakan suatu informasi tentang posisi keuangan perusahaan yang didalamnya terdapat laporan laba rugi, laporan perubahan ekuitas, neraca, laporan arus kas, dan catatan atas laporan keuangan.

Perusahaan yang ada di bidang jasa sering kali kesusahaan dalam mencatat keuangan yang ada pada perusahaannya. $\mathrm{Hal}$ ini dikarnakan adanya pendapatan dan beban-beban yang seharusnya ada pada periode-periode tertentu. Seperti misalnya uang muka yang dibayarkan oleh konsumen untuk bulan berikutnya, beban penyusutan sewa gedung dalam beberapa tahun kedepan, dan biaya lainnya. Dalam hal tersebut perusahaan haruslah dapat mengetahui cara-cara yang dapat mereka lakukan dalam mencatat keuangan perusahaannya.

Mideast Tour and Travel merupakan perusahaan jasa yang bergerak di bidang perjalanan haji dan umroh. Mideast Tour and Travel bertempat di jalan Kabupaten, Pamekasan. Perusahaan tersebut sering kali memberikan promo-promo untuk konsumen dengan cara yang unik dan praktis. Misalnya dengan cara memberikan kesempatan kepada konsumen atau calon jamaah umroh dengan cara mengangsur biaya umroh dalam waktu tiga bulan sebelum pemberangkatan. Dengan adanya promosi seperti itulah Mediast Tour and Travel harus mengetahui cara atau metode apa yang harus perusahaan gunakan untuk mencatat angsuran yang mereka berikan kepada konsumen. Tidak hanya itu, perusahaan juga harus lebih mengetahui cara mengatur bebanbeban yang akan dikeluarkan selama umroh berlangsung.

Sehubungan dengan hal
tersebut diatas, Maka peneliti
bermaksud untuk melakukan
penelitian yang berjudul "Analisis
Pengakuan Pendapatan dan Beban
serta Pengaruh Terhadap Laporan
Keuangan Pada Perusahaan Mideast
Tour and Travel Pamekasan".

\section{Rumusan Masalah}

Dari uraian diatas, terdapat beberapa masalah yang dapat peneliti rumuskan diantaranya:
1. Bagaimana
pendapatan
pengakuan pendapatan dan beban pada 
perusahaan Mideast Tour and Travel Pamekasan menurut PSAK 23?

2. Bagaimana dampak pada laporan keuangan atas pencatatan pengakuan pendapatan dan beban yang digunakan oleh perusahaan.

\section{Kerangka Pemikiran}

Adapun kerangka pemikiran pada penelitian kali ini diantaranya:

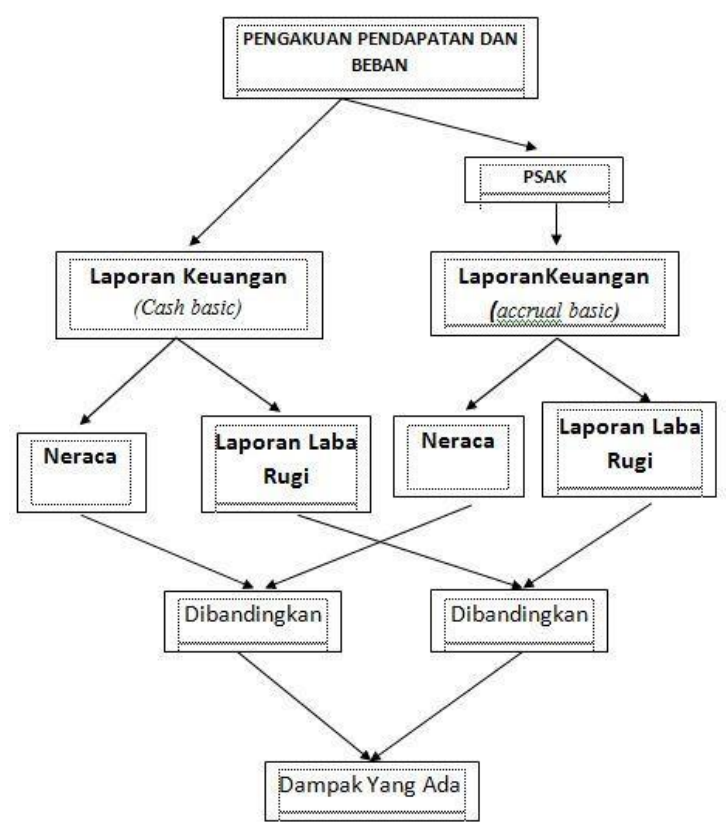

Gambar 1.1

Analisis Pengakuan Pendapatan dan

Beban Serta Pengaruh Laporan Keuangan

pada Midast Tour and Travel Pamekasan

\section{Tujuan Penelitian}

adapun tujuan dari penelitian ini adalah:

1. Untuk mengetahui metode yang di gunakan perusahaan Mideast Tour and Travel Pamekasan pada saat pengakuan pendapatan dan beban.
2. Untuk mengetahui dampak yang timbul dengan adanya metode yang dipakai perusahaan Mideast Tour and Travel Pamekasan dibandingkan dengan aturan PSAK 23 tentang pengakuan pendapatan.

\section{Landasan Teori Pendapatan}

Menurud Rismansyah, Nurlaili Safitri (2015:54) "pendapatan iyalah jumlah masukan yang didapat atas jasa yang diberikan oleh perusahaan yang bisa meliputi penjualan produk atau jasa kepada pelanggan yang diperoleh dalam suatu aktivitas operasi suatu perusahaan untuk meningkatkan nilai asset serta menurunkan liabilitas yang timbul dalam penyerahan barang atau jasa".

Sedangkan menurut Budi Mulia (2007:44) pendapatan yang timbul dari hasil penjualan jasa wisata diakui berdasarkan tour yang dilaksanakan, baik dari jenis tour yang dilakukan maupun lamanya perjalanan wisata yang telah dilakukan serta objek-objek wisata yang dikunjungi.

\section{Pengakuan Pendapatan}

Pengakuan pendapatan merupakan suatu proses pencatatan yang dilakukan oleh perusahaan untuk mengetahui seberapa banyak pendapatan yang perusahaan dapatkan pada periode tersebut.

Menurut Pawan dalam jurnal EMBA (2013: 351) selama ini ada dua dasar pengakuan dari pendapatan yaitu:

\section{Accrual basic}


Dasar accrual ini mengakui pendapatannya pada saat periode terjadinya transaksi pendapatan. Dengan dasar lain, pengaruh transaksi dan peristiwa lain diakui pada saat kejadian walaupun kas belum diterima.

\section{Cash basic}

Dasar tunai ini mengakui apabila pendapatan yang hanya diperhitungkan berdasarkan penerimaan dan pengeluaran kas. Dan penjualan barang atau jasa hanya dapat diperhitungkan pada saat tagihan langganan diterima.

\section{Beban}

Beban merupakan biaya yang dikeluarkan oleh perusahaan untuk kepentingan perusahaan tersebut dalam hal ini untuk mendapatkan keuntungan dari perusahaan itu sendiri.

Menurut para ahli, Rismansyah, Nurlaili syafitri (2015:54)

"beban adalah jumlah keluar dari harga perolehan terhadap barang atau jasa yang diserahkan, modal saham yang dibebankan sebagai imbalan dari barang atau jasa yang diterima perusahaan untuk memperoleh pendapatan dalam satu periode akuntansi akan terus melekat dan membentuk harga perolehan asset".

Beban tidak dapat terpisahkan dengan pendapatan perusahaan. Untuk mengetahui laba yang dimiliki perusahaan, makan perusahaan juga harus mengetahui beban yang perusahaan miliki pada periode tersebut. Beban juga dapat dibagi menjadi tiga yaitu.

1. Beban pemasaran Beban pemasaran merupakan beban yang digunakan perusahaan untuk mendapatkan atau menarik pelanggan agar pelanggan dapat tertarik kepada perusahaan tersebut. Contohnya pada saat pemberian iklat, pamphlet dan lainnya.

2. Beban administrasi

Beban administrasi juga dapat dapat dikatakan sebagai beban usaha dikarnakan beban administrasi juga merupakan beban yang digunakan perusahaan untuk mendapatkan keuntungan. Beban ini merupakan beban untuk membayar gaji karyawan, beban telfon listrik dan air, serta beban-beban lainnya yang mencakup pada kegiatan perusahaan.

3. Beban diluar usaha

Beban diluar usaha merupakan beban yang dikeluarkan oleh perusahaan untuk pengeluaran diluar usaha inti dari perusahaan tersebut. Sepeti missalnya beban bunga.

\section{Laporan Keuangan}

Menurut Myer mengatakan bahwa yang dimaksud dengan laporan keuangan adalah (2014:5):

"Dua daftar yang disusun oleh akuntan pada akhir periode untuk suatu perusahaan. Kedua daftar itu adalah daftar neraca atau daftar posisi keuangan dan daftar pendapatan atau daftar rugi laba. Pada waktu akhir-akhir ini sudah menjadi kebiasaan bagi perseroanperseroan untuk menambahkan daftar ketiga yaitu daftar sulus atau daftar laba yang tak dibagikan (laba yang ditahan)".

Laporan keuangan juga bersifat historis serta menyeluruh dan sebagai suatu progress report laporan keuangan terdiri dari data-data yang merupakan hasil dari suatu kombinasi antara: (Munawir.2004:6) 
1. Fakta yang telah dicatat (recorded fact)

2. Prinsip-prinsip dan kebiasaankebiasaan di dalam akuntansi (account-ing convention and postulate)

3. Pendapatan pribadi (personal judgment).

Dengan kata lain laporan keuangan dapat didefinisikan sebagai suatu kegiatan pencatatan yang dilakukan oleh akuntan pada akhir periode akuntansi, dimana ada 2 pencatatan yaitu laporan laba rugi dan neraca yang nantinya akan dipertanggung jawabkan oleh perusahaan kepada pihak-pihak terkait,baik itu pihak internal maupun eksternal untuk dapat menjadi perbandingan dalam pengambilan keputusan.

\section{Neraca}

Menurut Hery (2012:7) "Neraca adalah suatu laporan yang sistematis tentang posisi aktiva, kewajiban dan ekuitan perusahaan per tanggal tertentu. Neraca juga bertujuan untuk menggambarkan posisi keuangan perusahaan".

Neraca adalah laporan keuangan yang menunjukkan posisi keuangan dalam suatu perusahaaan seperti diantaranya aktiva, hutang dan ekuitas pada satuperiode. Ada dua bentuk neraca yaitu:

1. Bentuk rekening atau skontro (account form) dalam bentuk ini neraca dibagi dua yaitu aktiva dan pasiva. Aktiva ada pada posisi sebelah kiri dan pasiva di tempatkan di sebelah kanan.

2. Bentuk laporan neraca bentuk laporan ini dapat disusun dengan meletakkan aktiva diatas dan pasiva di bawahnya.
Dari kedua bentuk neraca diatas, sering kali seorang akuntan menggunakan bentuk tersebut tergantung dengan bentuk mana yang dirasa mudah. Neraca yang dibuat oleh akuntan nantinya akan dibaca oleh pihak yang berkepentingan dalam perusahaan tersebut, oleh karnanya akuntan harus benar-benar mengetahui bentuk mana yang dirasa mudah oleh pihak terkait dalam membaca neraca tersebut.

\section{Laporan Laba Rugi}

Laporan laba rugi adalah laporan yang menunjukkan kemampuan perusahaan dalam menghasilkan laba selama suatu periode akuntansi atau satu tahun. Untuk mengetahui laba yang diperoleh perusahaan dalam suatu periode, akuntan dapat memperhitungkan dengan cara mengurangkan pendapatan yang didapat oleh perusahaan dengan beban yang dikeluarkan perusahaan dalam periode yang sama.

Menurut Hery (2012:4), laporan laba rugi (income statement) merupakan laporan yang sistematis tentang pendapatan dan beban perusahaan untuk suatu periode tertentu.

Terdapat dua bentuk laporan laba rugi diantaranya:

1. Bentuk langkah tunggal (single stap form). Bentukini biasanya digunakan oleh perusahaan kecil dikarnakan bentuk langkah tunggal lebih gampang dan praktis pencatatannya.

2. Bentuk langkah bertahap (multiple step form). Bentuk ini dapat menentukan berbagai laba yang didapat oleh perusahaan. sering kali bentuk ini digunakan oleh perusahaan-perusahaan besaruntuk 
mengetahui laba apa saja yang telah perusahaan dapatkan.

\section{PSAK 23}

Penurut PSAK 23 tahun 2014 pada paragraph 21 dinyatakan "pengakuan pendapatan dengan mengacu pada tingkat penyelesaian dari suatu transaksi sering disebut sebagai metode presentase penyesuaian. Dengan metode ini, pendapatan diakui dalam periode akuntansi pada saat jasa diberikan. Pengakuan pendapatan atas dasar ini memberikan informasi yang berguna mengenai tingkat kegiatan jasa dan kinerja dalam suatu periode". oleh karnanya perusahaan haruslah melakukan penyesuaian pada saat jasa telah diberikan. Dengan demikian perusahaan dapat mengakuinya sebagai pendapatan.

Sedangkan pada paragraph 22 menyebutkan "pendapatan diakui hanya jika kemungkinan besar manfaat ekonomik sehubungan dengan transaksi jumlah yang telah masuk dalam pendapatan, maka jumlah yang tidak tertagih atau jumlah pemulihan yang kemungkinannya tidak lagi besar diakui sebagai beban, Bukan sebagai penyesuaian terhadap jumlah pendapatan yang diakui semula". Dalam keterangan tersebut apabila terdapat seorang pelanggan melakukan pembayaran namun pelanggan tersebut membatalkan untuk menerima jasa kita, maka pendapatan tersebut nantinya akan dinyatakan sebagai beban tidak lagi melakukan penyesuaian pada periode tersebut.

\section{METODE PENELITIAN}

\section{Lokasi Penelitian}

Pada penelitian penulis memilih objek di Mideast Tour and Travel. Yang bertempat di jalan Kabupaten, kota Pamekasan. Penulis memilih objek tersebut dikarnakan Mideast Tour and Travelsangat sesuai dengan judul yang akan penulis bahas saat ini.

\section{Jenis Penelitian}

Jenis penelitian penulis menggunakan pendekatan deskriptif kuantitatif. Pendekatan ini merupakan rangkaian analisis data yang berbentuk angka yang diolah dengan cara menghitung dan membandingkan data tersebut dengan metode lain selain pada data yang ada pada objek tersebut. Teknik analisis data yang digunakan oleh penulis berupa perbandingan metode cash basic dan accrual basic.

\section{Jenis dan Sumber Data}

Jenis data pada penelitian ini iyalah data kuantitatif dimanadata yang penulis dapatkan berupa angkaangka dan nantinya akan dianalisis dengan cara penghitung dan membandingkan kedua metode yang ada. Sumber data yang penulis dapatkan melalui data primer. Dimana peneliti mengambil dokumentasi berupa data laporan keuangan pada objek penelitian yaitu Mideast Tour and Travel. Serta data sekunder dengan cara sedikit wawancara dengan pemilik perusahaan.

\section{Definisi Operasional Variable}

Definisi operasional dalam penelitian ini adalah:

1. Pengakuan pendapatan dan beban adalah pengakuan yang terjadi di perusahaan Mideast Tour and Traveldengan indikasi : 

a. Pengakuan pendapatan di Mideast Tour and Travel
b. Pengakuan beban di Mideast Tour and Travel

2. Laporan keuangan adalah laporan keuangan pada perusahaan Mideast Tour and Traveldengan indikasi diantaranya :
a. Laporan laba rugi
b. Neraca

\section{Teknik Pengumpulan Data}

\begin{abstract}
Teknik pengumpulan data yang penulis pakai adalah teknik dokumentasi yaitu dengan mengumpulkan dokumen-dokumen yang dibutuhkan untuk penelitian dari narasumber yang dipercaya, yaitu data-data laporan keuangan yang terdapat pada perusahaan. Serta sedikit wawancara dengan pemilik perusahaan Mideast Tour and Travelmengenai sejarah Mideast Tour and Travelsendiri.
\end{abstract}

\section{Teknik Analisis Data}

Teknik analisis data yang nantinya akan penulis laksanakan pada penelitian ini diantaranya sebagai berikut:
1. Langkah pertama yang akan penulis lakukan ialah melakukan pengumpulan data yang dibutuhkan oleh penulis pada perusahaan Mideast Tour and Travel.yang meliputi data pendapatan pada perusahaan tersebut, bebanbeban yang dimiliki oleh perusahaan, serta data-data pendukung lainnya.

2. Selanjutnya penulis akan menganalisis data-data yang didapat serta membuat laporan keuangan pembanding yaitu laporan keuangan yang menggunakan accrual basic

3. Setelah data tersebut dianalisis, maka hasil dari analisis tersebut akan diperbandingkan satu samalain yaitu laporan keuangan milik perusahaan dan laporan keuangan pembanding dengan mendasarkan pembuatan laporan keuangan dengan PSAK.

4. Selanjutnya, langkah terakhir penulis akan menyimpulkan hasil dari analisis tersebut.

\section{HASIL PENELITIAN DAN PEMBAHASAN}

\section{Sumber dan Jenis Pendapatan}

Pendapatan pada Mideast Tour and Travel adalah pendapatan yang diperoleh dari kegiatan aktifitas perusahaan. Seperti pendapatan umroh yang dapat diangsur 3bulan sebelum pemberangkatan. Jamaah juga dapat langsung membayar angsurannya kepada kantor Mideast Tour and Travel yang bertempat di jalan Kabupaten Kota Pamekasan.
Mideast Tour and Travel hanya memprioritaskan paket-paket umroh yang ada saat ini. Setiap tahun Mideast Tour and Travel selalu memberikan promo-promo dengan harga yang berbeda.

Pada tahun 2014 perusahaan memberikan paket umroh kepada jamaah dengan nominal: 
1. program regular dengan harga Rp. 28.500.000,selama 12 hari

2. program promo dengan harga Rp. 25.000.000,- selama 10 hari

terdapat 894 total jamaah yang telah Mideast berangkatkan. Dengan 327 jamaah menggunakan program regular dan 567 jamaah menggunakan program promo.

pada tahun 2015 perusahaan memberikan paket umroh kepada jamaah dengan nominal :

1. program regular dengan harga Rp. 24.000.000,selama 12hari

2. program promo dengan harga Rp. 20.000.000,- selama 10 hari

terdapat 1061 total jamaah yang mempercayai Mideast sebagai travel pemberangkatan umroh. Dengan 584 jamaah menggunakan program regular, dan 477 jamaah menggunakan program promo.

pada tahun 2016 perusahaan memberikan paket umroh kepada jamaah dengan nominal :

1. program regular dengan harga Rp. 27.500.000,selama 12 hari

2. program promo dengan harga Rp. 22.000.000,- selama 10 hari

pada tahun 2016 ini terdapat 1964 total jamaah yang mempercayai Mideast dengan 408 jamaah menggunakan program regular dan 1556 jamaah penggunakan program promo

sedangkan sebangai pandangan pada tahun ini Mideast Tour and
Travel akan memberikan paket perjalanan umroh yang lebih ekonomis yaitu:

1. program VIP dengan harga Rp. 35.000.000,- selama 13 hari

2. program regular dengan harga Rp. 26.500.000,selama 12 hari

3. program promo dengan harga Rp. $18.500 .000,-$ selama 10 hari

Dari pendapatan tersebut perusahaan dapat mengambil keuntungan kurang lebih 20\%- 25\% dari pembayaran para jamaah.

Mideast Tour and Travel juga memberikan jasa pembuatan pasport kepada calon jamaah yang tidak ingin mengmengurusnya sendiri. Perusahaan hanyalah memberikan tambahan harga 150.000,- setiap calon jamaah dari harga pembuatan pasport pada umumnya. Dengan kegiatan tersebut calon jamaah lebih mudah untuk segera berangkat sesuai jadwal yang telah ditentukan oleh perusahaan Mideast tour and travel.

\section{Pengakuan Pendapatan}

Pengakuan pendapatan pada Mideast Tour and Travel yaitu menggunakan metode cash basic. Dimana pendapatan yang didapat perusahaan akan dihitung sesuai keberadaan kas saat itu.

Dari hasil penelitian ini penulis mendapatkan data-data pendapatan perusahaan setiap tahunnya dari tahun 2014-2015 sebagai berikut

\begin{tabular}{|l|l|l|l|l|}
\hline no & Keterangan & 2014 & 2015 & 2016 \\
\hline
\end{tabular}


ISSN 1412-2936

\begin{tabular}{|l|l|r|r|r|}
\hline 1 & $\begin{array}{l}\text { Penjualan } \\
\text { kuota umroh }\end{array}$ & Rp.23.454.500.000 & Rp.23.520.000.000 & Rp.45.392.000.000 \\
\hline 2 & $\begin{array}{l}\text { Pendapatan } \\
\text { paspor }\end{array}$ & Rp.327.600.000 & Rp.335.700.000 & Rp.923.140.000 \\
\hline & $\begin{array}{l}\text { Jumlah } \\
\text { pendapatan }\end{array}$ & Rp.23.782.100.000 & Rp.23.855.700.000 & Rp.46.315.140.000 \\
\hline
\end{tabular}

Pada tahun 2014-2015 perusahaan memiliki pendapatan yang signifikan sedangkan pada tahun 2016 pendapatan yang dimiliki perusahaan melambung naik hingga $50 \%$. Keadaan ini diprediksi karna adanya sponsor/iklan yang telah perusahaan buat di muka umum.

\section{Pengakuan Beban}

Dari hasil penelitian pada perusahaan Mideast Tour and Travel, penulis mendapatkan jumlah data biaya yang dikeluarkan pada tahun 2014-2016 diantaranya:

\begin{tabular}{|c|c|c|c|}
\hline Keterangan & 2014 & 2015 & 2016 \\
\hline Beban operasi & Rp. 16.351.108.666 & Rp. 17.628.029.556 & Rp. 34.992.778.890 \\
\hline
\end{tabular}

\section{Dampak laporan keuangan perusahaan yang akan didapat}

Mideast Tour $\begin{array}{r}\text { and } \\ \text { laporan }\end{array}$
Travelmenggunakan
keuangan cash basic dimana pada
laporan keuangan ini dilaporkan pada
saat perusahaan menerima kas
ataupun mengeluarkan kas
perusahaan. Dalam laporan laba rugi
perusahaan sangatlah nyata
keberadaan kas perusahaan dari
pada laporan accrual yang nantinya
akan menjadi pembanding laporan
keuangan perusahaan. Laporan
keuangan accrual basic tersebut telah
terdaftar dalam PSAK 23 yang
mengatur tentang pendapatan. Laba
perusahaan dapat dikatakan
signifikan ketika laba yang diperoleh
perusahaan setiap periode semakin
bertambah. Laba akan bertambah
dapat dilihat dari pendapatan yang
didapat oleh perusahaan dan beban-
beban yang dikeluarkan pada saat
periode tersebut. apabila pendapatan
dan beban-beban tersebut salah

pengakuannya, maka laba yang dihasilkan juga tidak dapat diakui laba pada saat periode tersebut. Pada tabel diatas terdapat selisih antara laporan keuangan cash basic dan laporan keuangan accrual basic. Dari selisih tersebut terdapat beberapa pengakuan yang harus diakui dan yang tidak perlu diakui pada saat periode tersebut. Diantaranya:

Total pendapatan kuota umroh pada tahun 2016 senilai Rp. 45.392.000.000yang telah dibayar pada tahun 2015 senilai Rp. 990.000.000 maka jumlah sisa pendapatan yang diterima senilai Rp.44.402.000.000.

Dapat kita ketahui pada laporan laba rugi diatas, perusahaan Mideast Tour and Travelmenggunakan laporan keuangan cash basic dimana laporan keuangan yang nyata didalam perusahaan. Sedangkan laporan keuangan accrual basic merupakan laporan keuangan pembanding yang diolah berdasarkan acuan PSAK yang 
berlaku di Indonesia. Perbedaanperbedaan tersebut dapat diliat pada laporan keuangan yang terdapat pada tabel-tabel diatas. Terlihat jelas perbedaan pada kedua laporan keuangan yang berbeda tersebut. pada tahun 2014 dari jumlah pendapatan terdapat selisih Rp.2.000.000.000 yang diakibatkan terjadinya pencatatan yang diakui oleh laporan laba rugi perusahaan yaitu dengan menggunakan metode cash basic lebih besar dibandingkan laporan laba rugi pembanding. Pendapatan selisih tersebut merupakan pendapatan yang seharusnya diakui pada tahun berikutnya. Sedangkan pada sisi beban selisih yang didapat oleh laporan laba rugi diatas sebesar Rp. 1.310.000.000 dimana yang membedakan beban-beban tersebut dikarnakan adanya pencatatan yang berbeda pada beban sewa kantor, danbeban pembelian tiket pesawat. Dengan demikian laba/rugi yang didapat tidak sama dan memiliki selisih begitu pula dengan pajak yang dimilikinya.

Pada perusahaan Mideast Tour and Travel yang dapat diterapkan iyalah tarif pajak yang ke dua karna pendapatan perusahaan berkisar Rp 22.845.700.000 - Rp 45.695.140.000. adapun rumus yang digunakan
Pajak penghasilan badan $=\{0,25-$ $(0,6$ miliar/penghasilan kotor $)\} \quad X$ penghasilan kenak pajak (PKP)

Dengan membandingkan
laporan laba-rugi tersebut dapat
diketahui selisih laba yang di dapat
pada kedua laporan keuangan yang
ada. Pada tahun 2014 selisih laba
bersih setelah pajak

Rp.2.547.550.803 pada tahun 2015 selisih laba bersih setelah pajak (Rp765.473.801) dan pada tahun 2016 selisih laba bersis setelah pajak sebesar (Rp.402.484.829)

Pada masing-masing laporan laba rugi diatas terdapat selisih satu sama lain dikarnakan pada laporan cash basic masih adanya biaya yang belum dibayar atau biaya yang seharusnya diakui pada tahun setelahnya diakui pada periode saat ini. Ataupun adanya pendapatan yang seharusnya diakui tahun yang akan datang namun diakui pada periode saat ini.

Mideast Tour and Travel juga memiliki alasan khusus mengapa perusahaan mencatat keuangannya dengan metode cash basic. Karna metode cash basic lebih gampang digunakan dan dapat melihat jumlah kas perusahaan pada saat periode tersebut. 


\section{Kesimpulan}

Pengakuan pendapatan dan
beban pada perusahaan Mideast
Tour and Travelmenggunakan
metode cash basic. Dimana metode
cash basic merupakan metode yang
mencatat pendapatan dan bebannya
dengan cara penghitung kas yang
telah ada pada perusahaan.
Perusahaan menggunakan
pengakuan tersebut dikarnakan
menurut perusahaan lebih tepat
dalam menghitung kas yang ada
pada perusahaan saat itu. Namun
pada kenyataannya pada pengakuan
cash basic inilah tidak dapat diakui
yang sebenarnya mendapatan dan
beban pada periode yang berjalan
saat itu. Karna apabila merusahaan
menggunakan metode cash basic
belum tentu semua beban ataupun
pendapatan perusahaan akan tercatat
pada periode tersebut.

Dampak yang timbul dengan pencatatan menggunakan metode yang digunakan perusahaan yaitu cash basic iyalah perusahaan Mideast Tour and Traveltidak dapat mencatat seluruh pendapatan dan beban yang seharusnya diakui pada periode yang sedang berjalan. Perusahaan Mideast Tour and Traveltidak dapat memberikan laporan keuangan yang akurat karna perusahaan belum berpedoman pada PSAK 23 tentang pengakuan pendapatan yang seharusnya digunakan dalam melakukan pencatatan laporan keuangan.

\section{Saran}

Dari kasus diatas dapat peneliti sarankan perusahaan Mideast Tour and Travel dapat mengganti laporan keuangan menggunakan laporan keuangan accrual basic agar dapat menjadikan laporan keuangan yang perusahaan miliki akurat dalam menginformasikan hasil keuangan perusahaan dalam satu periode dan periode-periode berikutnya.

\section{DAFTAR PUSTAKA}

Budi Mulia. 2007. Pengakuan dan Pengukuran Pendapatan Menurut PSAK NO 23 Pada PT. Raya Utama Travel Medan; Skripsi Universitas Sumatera Utara Medan

Hery. 2012. Analisis Laporan Keuangan; Penerbit Bumi Aksara. Jakarta.

Ikatan Akuntansi Indonesia. 2014. Standar Akuntansi Keuangan; Graha Akuntan. Jakarta

Munawir. 2004. Analisis Laporan Keuangan; Penerbit Liberty. Yogyakarta.

Pawan. Elisabeth Caroline. 2013. Pengakuan. Pengukuran. Pengungkapan. dan Pelaporan Pendapatan Berdasarkan PSAK 23 Pada PT. Pegadaian (Persero); Jurnal EMBA Vol1 No 3 juni 2013 Halm 349-356. Manado

Rismansyah dan Nurlaili Safitri. 2015. Analisis Pengakuan Pendaptan dan Beban pada PT Wahana Bumi Riau Cabang Palembang; jurnal media wahana ekonomika. Vol 12. no 2. juli 2015: 51-74. Palembang

Rudianto. 2012. Pengantar Akuntansi; Penerbit Erlangga. Jakarta.

Sari Apsa. 2013."Evaluasi Pengakuan .Pengukuran. dan Pelaporan Pendapatan Berdasarkan PSAK no. 23 
Pada PT. Pelayaran Liba Marindo Tanjung Pinang Periode 2013"; Universitas Maritim Raja Ali Haji. Tanjungpinang

Subramanyam dan John J. Wild. 2014. Analisis Laporan Keuangan; Penerbit Salemba Empat. Jakarta.
Sugiyono. 2012. Metode Penelitian Kuantitatif Kualitatif dan R\&D: Alfabeta. Bandung.

Tanti Kurniawati. 2014. Analisis Recognition dan Measurement Pendapatan menurut PSAK 23 Pada Tjahaja Baroe Group Surabaya; Skripsi Universitas Wijaya Putra.Surabaya. 